\title{
Clinical factors associated with rape victims' ability to testify in court: a records-based study of final psychiatric recommendation to court
}

TD Phaswana, D Van der Westhuizen, C Krüger

Department of Psychiatry, Weskoppies Hospital, University of Pretoria, Pretoria, South Africa

\begin{abstract}
Objective: A rape victim may encounter professionals in both the health and the legal systems. Unanswered questions remain about clinical factors associated with a rape victim's ability to testify in court, and the quality of care offered to rape victims. The objectives of this study were thus to determine the clinical factors that are associated with a rape victim's ability to testify in court, as well as to undertake a preliminary exploration of the referral system between the court and the mental health services. Method: A retrospective study was conducted of rape victims referred by the court $(n=70)$ to be assessed psycho-legally by psychiatrists. Rape victims who were recommended as able and those recommended as unable to testify in court were compared with regard to their clinical characteristics. Results: Thirty-seven (53.6\%) victims were recommended as able to testify and 32 (46.4\%) victims as unable to testify in court. Victims from rural areas and victims with severe mental retardation were statistically significantly more often found to be unable to testify in court. Almost half (49.2\%) of the victims were referred by court for first assessment within six months of being raped. Most (63.5\%) victims were assessed for the first time within one month of being referred. Conclusion: The decision about a victim's ability to testify should not be based solely on the two statistically significant variables but, rather, individualised. Optimal mental health and legal services should be offered to rape victims. Further studies are required in assessing the collaboration between the health and legal systems.
\end{abstract}

Keywords: Rape victims; Court referral; Psycho-legal assessment; Ability to testify in court; Mental retardation

Received: 19-04-2012

Accepted: $13-11-2012$

doi: http://dx.doi.org/10.4314/ajpsy.v16i5.46

\section{Introduction}

Rape is a serious problem worldwide, with statistics from South African Police Services showing a total of 66196 reported cases from 1st April 2010 to 31st March 2011. Individuals with mental disorders, especially those with mental retardation, are at high risk of falling victim to sexual offences. Estimates of sexual victimisation of the mentally retarded population ranges from $14 \%$ to $96 \%$ or 4 to 10 times the rate of the non-disabled population. ${ }^{2}$ Only $3 \%$ of cases of sexual abuse involving people with developmental disabilities are reported to authorities. ${ }^{2}$ The lack of reporting makes it difficult to assess accurately the incidence of such crimes. ${ }^{2}$

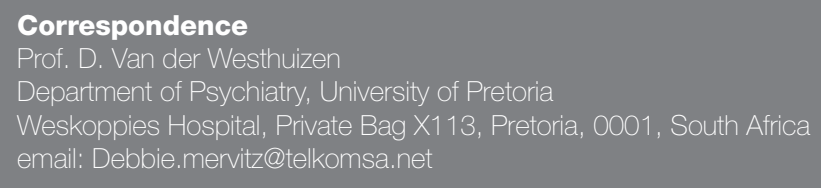

Rape is one of the most severe of all traumas, causing multiple long-term negative outcomes such as anxiety disorders, mood disorders and chronic physical health problems. $3,4,5$ Sexual abuse is a significant risk factor for the development of psychopathology in childhood, adolescence and adulthood. ${ }^{6}$ This outcome may also have a negative impact on the victim's ability to testify in court.

Investigations and prosecution procedures are critical to the prevention of sexual abuse, in that failure to convict offenders allows for the continuation of abuse without perpetrators' fear of punishment, ${ }^{2,7}$ Often the victims are required to testify in court where they are questioned about the elements of the crime over and over again to check for consistency in their accounts. This can be emotionally unsettling, given that trauma can impede concentration and memory. ${ }^{3}$

If the court is in doubt as to whether a victim is competent to testify, then the victim is referred to a mental health care 
practitioner (MCHPs) for psycho-legal assessment. This normally involves assessment of: the ability to testify in court, the ability to consent to sexual behaviours, the ability to distinguish between right and wrong and clinical intellectual capacity (referred to by the courts as 'mental age' of victim). After assessment is completed, the victim is referred back to the court with a report compiled by the MHCP.

At times victims are children $\left(<18\right.$ years old). ${ }^{8}$ The majority of children are abused more than once by the same abuser and they know their abusers before commencement of the abuse. ${ }^{6}$ The situation becomes even more difficult if these children have a mental illness - either pre-existing or as a consequence of rape. In this regard, the ability of the children to testify in the court can be severely compromised, as sometimes the perpetrator stays in the same household with the child or stays in the neighbourhood. Pillay found that $14.2 \%$ of perpetrators were relatives or family friends of the victim and in $77.4 \%$ of cases perpetrators were people in the community whom the rape victim had previously seen but not befriended. ${ }^{9}$

MHCPs are required to assess if the victim will be able to testify in an open court or would need special assistance during their testimony. The ability to testify is important, as the Service Charter for Victims of Crime in South Africa provides victims with the right to fair and dignified treatment, and the offering and receiving of information, protection, assistance, compensation and restitution. ${ }^{10,11}$ The Criminal Procedures Act No 51 of 1977 makes provision for victims to testify with the help of intermediaries as well as for those who may not testify in an open court. ${ }^{12}$

The presumption of incompetency has been particularly detrimental for people with mental retardation. ${ }^{2}$ Pillay audited 106 rape survivors and found that almost $80 \%$ of the victims were classified as suffering from moderate or severe mental retardation, and over $90 \%$ were able to testify. The study indicated to the judiciary system that despite cognitive disabilities found in people with mental retardation, these individuals have the capacity to testify and should be given the opportunity. ${ }^{9}$ Similarly, Valenti-Hein and Schwartz also emphasise that people with mental retardation need to be given the opportunity of testifying in court, as denial of the ability to serve as a witness is a denial of justice. ${ }^{2}$

Owing to their extensive post-sexual assault needs, victims may turn to multiple social systems for assistance. ${ }^{3}$ When victims reach out for help, they place a great deal of trust in the legal, medical and mental health systems as they risk disbelief, blame and refusal of help. How these system interactions unfold can have profound implications for victims recovery. ${ }^{3}$

Several previous studies have examined the consequences of rape or psychopathology after rape. , $4,5,13,14$ Few previous studies have evaluated rape victims with mental illness and their ability to testify in court. 2,7,9 These few studies emphasise the need for focusing on victims' mental health needs, and the need for a good interaction between the judicial and the mental health services (MHS). The studies also emphasise that mental illness has an impact on the ability to testify in court, but those victims still have a right to be given a chance to testify on their own if the assessor and the court are of the opinion that they are able to testify. However, no previous studies have explored the clinical factors associated with rape victims' ability to testify in court. Also, no previous studies have audited the quality of care offered to rape victims with regard to the interaction between the judiciary and the MHS.

The objectives of this study were thus to determine the clinical factors that were associated with a rape victim's ability to testify in court as well as to undertake a preliminary exploration of the referral system between the courts and the MHS (especially Weskoppies Hospital/WKH, which is a specialised psychiatric hospital located in Pretoria and a designated site for forensic assessments).

\section{Method}

\section{Study design}

A retrospective file review was conducted. Two groups of rape victims were compared with regard to their clinical characteristics. Those two groups were victims who were recommended as being able to testify (on their own or with help of an intermediary and/or in camera) and those recommended as being unable to testify in court.

\section{Subjects}

The study assessed 70 files of rape victims who had been referred by the courts to WKH for assessment of their ability to testify in court, ability to consent to sexual behaviours, ability to distinguish between right and wrong, for clinical intellectual capacity (referred to by the courts as 'mental age' of the victim) and for capacity to understand and follow court procedures.

Victims under 18 years of age had been assessed by child psychiatrists and psychologists working at the Child- and Adolescent Unit. Victims above 18 years of age had been assessed by general adult psychiatrists and psychologists of WKH. The victims had been assessed as outpatients. The study included victims who had been assessed by the psychiatrists from January 2006 to December 2009.

The psycho-legal assessment had taken into consideration victims' perinatal and developmental history, current academic performance and school functioning, current mental state evaluation, clinical assessment of their cognitive abilities that included a Folstein Mini Mental State Examination, as well as the coherence of their narrative account of the rape incident and the way that it affected their life since the incident.

Qualified psychiatric nurses had acted as interpreters in cases of language barriers. Victims' language abilities had not specifically been assessed and no psychometric intelligence testing had been done because of the lack of validated, standardised measures for South African population groups.

\section{Measurements}

For this study, demographic details, details of the rape incident, history of mental illness before the rape, DSM-IV-TR diagnoses after assessment, treatment given before final evaluation and final recommendation of the psychiatrist's evaluation were recorded.

\section{Data analysis}

Data analysis consisted of descriptive statistics such as crosstabulations of categorical variables, means and standard deviations. Chi-Squared and Fisher Exact tests were used where applicable. Where the victim had more than one diagnosis, multiple response analysis was used. 


\section{Ethics}

Ethics approval was obtained from the Faculty of Health Sciences Research Ethics Committee at the University of Pretoria before the study was commenced. A waiver of written informed consent was obtained. Permission to access the information from the victims' files was obtained from the Chief Executive Officer of WKH.

\section{Results}

Descriptive statistics

Demographic details are summarised in Table I. The mean age at the date of rape was 22.5 years (SD 15.3), with almost two-thirds between ages 7.2 and 37.8 years. The youngest victim was 4 years old and the oldest was 83 years old. The mean age at the date of assessment was 23.4 years (SD 14.9). The majority of the victims were black ( $n=53 ; 75.7 \%)$ and were children of $\leq 18$ years at the time of the rape $(n=38$ $58.4 \%)$. More than half ( $n=38 ; 54.3 \%)$ of the victims attended special schools. The majority $(n=50 ; 71.4 \%)$ were residing in a city/town/township. Sixty-five (92.9\%) victims stayed with their family. Many ( $n=30 ; 42.9 \%)$ of the victims were raped in their own homes. Forty (57.1\%) were raped by someone who was known to the community. Forty-four (62.9\%) were raped for the first time.

Table II summarises the period between the date of the rape and court referral to WKH and between court referrals to WKH and first assessment at WKH. Almost half ( $\mathrm{n}=30$; $49.2 \%$ ) of the victims were referred by the court to WKH for the first assessment within six months of being raped. Most ( $n=40,63.5 \%$ ) victims were assessed for the first time within one month of being referred to WKH by court.

Of all the victims who were assessed for the first time $(n=70)$, ten victims were assessed more than once. Out of those ten victims who were assessed more than once, nine ( $90 \%$ ) victims were re-assessed within four weeks after the first assessment.

In terms of history of mental illness before psycho-legal assessment, only $5.4 \%$ of the victims had a history of mood disorders, $2.7 \%$ of psychotic disorders, and $4.1 \%$ of dementia. A history of mental retardation was found in $12.2 \%$

\begin{tabular}{|l|l|l|}
\hline \multicolumn{2}{|l|}{$\begin{array}{l}\text { Table II: Period between rape, court referral and 1st } \\
\text { assessment }\end{array}$} & \multicolumn{2}{|l|}{ Number of victims = 70} \\
\hline \multicolumn{2}{|l|}{ Frequency } & Percentage (\%) \\
\hline & & \\
\hline Period between date of rape and & & \\
court referral to WKH & 30 & 49.2 \\
$0-6$ months & 12 & 19.7 \\
$7-12$ months & 11 & 18.0 \\
$13-24$ months & 8 & 13.1 \\
$>25$ months & & \\
\hline Period between court referrals \\
and 1st assessment at WKH \\
1 month & 40 & 63.5 \\
1 month & 14 & 22.2 \\
2 months & 5 & 7.9 \\
3 months & 4 & 6.3 \\
\hline
\end{tabular}

\begin{tabular}{|c|c|c|}
\hline & \multicolumn{2}{|c|}{ Number of victims $=70$} \\
\hline & Frequency & Percentage (\%) \\
\hline $\begin{array}{l}\text { Gender } \\
\text { Female } \\
\text { Male }\end{array}$ & $\begin{array}{l}58 \\
12\end{array}$ & \begin{tabular}{|l|}
82.9 \\
17.1
\end{tabular} \\
\hline $\begin{array}{l}\text { Age at date of rape } \\
4-18 \text { years } \\
19-30 \text { years } \\
>30 \text { years }\end{array}$ & $\begin{array}{l}38 \\
12 \\
15\end{array}$ & $\begin{array}{l}58.4 \\
18.5 \\
23.1\end{array}$ \\
\hline $\begin{array}{l}\text { Age at } 1 \text { st assessment } \\
4-18 \text { years } \\
19-30 \text { years } \\
>30 \text { years }\end{array}$ & $\begin{array}{l}38 \\
15 \\
16\end{array}$ & $\begin{array}{l}55.1 \\
21.7 \\
23.2\end{array}$ \\
\hline $\begin{array}{l}\text { Race } \\
\text { Black } \\
\text { White } \\
\text { Coloured }\end{array}$ & $\begin{array}{l}53 \\
14 \\
3\end{array}$ & $\begin{array}{l}75.7 \\
20.0 \\
4.3\end{array}$ \\
\hline $\begin{array}{l}\text { Marital status } \\
\text { Single } \\
\text { Married } \\
\text { Divorced } \\
\text { Widowed }\end{array}$ & $\begin{array}{l}65 \\
1 \\
1 \\
2\end{array}$ & $\begin{array}{l}92.9 \\
1.4 \\
1.4 \\
2.9\end{array}$ \\
\hline $\begin{array}{l}\text { Highest level of education } \\
\text { Special school } \\
\text { Primary school } \\
\text { High school } \\
\text { Tertiary and other education } \\
\text { Never schooled }\end{array}$ & $\begin{array}{l}38 \\
15 \\
6 \\
2 \\
5\end{array}$ & \begin{tabular}{|l|}
54.3 \\
21.4 \\
8.6 \\
2.9 \\
7.1
\end{tabular} \\
\hline $\begin{array}{l}\text { Residential category } \\
\text { City/Town/Township } \\
\text { Rural } \\
\text { Squatter camps } \\
\text { Unknown }\end{array}$ & $\begin{array}{l}50 \\
13 \\
4 \\
3\end{array}$ & $\begin{array}{l}71.4 \\
18.6 \\
5.7 \\
4.3\end{array}$ \\
\hline $\begin{array}{l}\text { With whom was the victim living } \\
\text { Family } \\
\text { Alone } \\
\text { Children's home or shelter }\end{array}$ & $\begin{array}{l}65 \\
2 \\
3\end{array}$ & $\begin{array}{l}92.9 \\
2.9 \\
4.3\end{array}$ \\
\hline $\begin{array}{l}\text { Place of rape incident } \\
\text { Victim's home } \\
\text { Perpetrator's home } \\
\text { Veldt } \\
\text { Other places } \\
\text { Unknown }\end{array}$ & $\begin{array}{l}30 \\
18 \\
6 \\
7 \\
9\end{array}$ & \begin{tabular}{|l|}
42.9 \\
25.7 \\
8.6 \\
10.0 \\
12.9 \\
\end{tabular} \\
\hline $\begin{array}{l}\text { Relation to perpetrator } \\
\text { Someone in the community } \\
\text { Parent (biological/step-) } \\
\text { Other relatives } \\
\text { Unknown } \\
\text { Other }\end{array}$ & $\begin{array}{l}40 \\
4 \\
7 \\
13 \\
4\end{array}$ & \begin{tabular}{|l|}
58.8 \\
5.9 \\
10.0 \\
19.1 \\
5.9
\end{tabular} \\
\hline $\begin{array}{l}\text { Rape incident } \\
\text { First } \\
\text { Recurrent } \\
\text { Unknown }\end{array}$ & $\begin{array}{l}44 \\
21 \\
5\end{array}$ & $\begin{array}{l}62.9 \\
30.0 \\
7.1\end{array}$ \\
\hline
\end{tabular}


of the victims; however, $54.3 \%$ of the victims were already attending a special school, which means that they were probably known to have some form of mental retardation before assessment.

After assessment, $40.2 \%$ of victims were diagnosed with a mood disorder and $23.2 \%$ with an anxiety disorder. The distribution of primary Axis I diagnosis after assessment is represented in Figure 1.

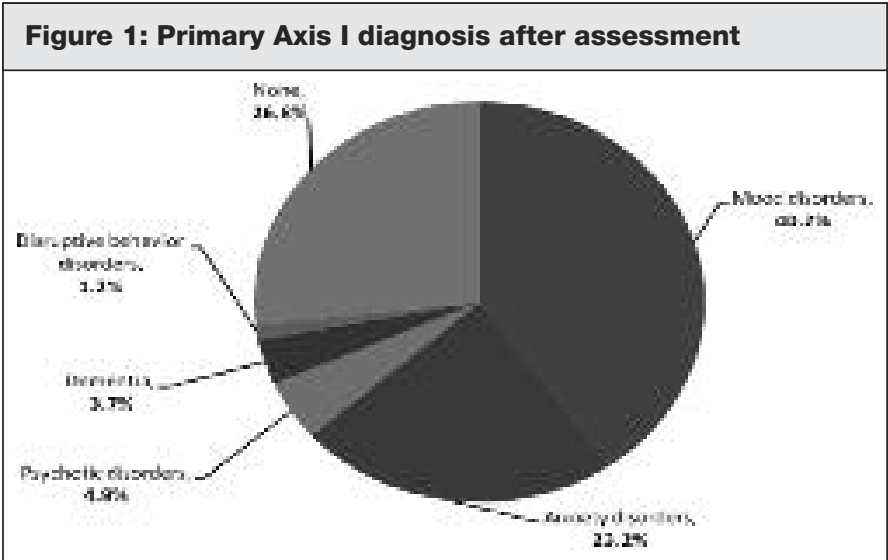

Most (84.3\%) of the victims were diagnosed with mental retardation after assessment. The largest subgroup (40.0\%) was assessed as having moderate mental retardation. The distribution of mental retardation diagnosis is represented in Figure 2.

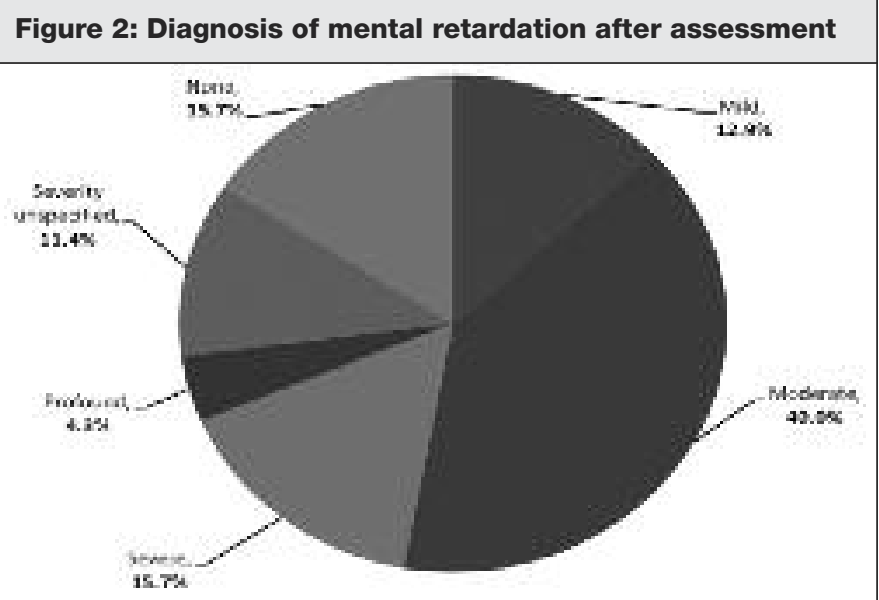

Most (57.5\%) of the victims were not diagnosed with a general medical condition (GMC). Out of the victims who had a GMC diagnosis, epilepsy was found to be the most common (35.5\%). Old head injury was diagnosed in $19.4 \%$ of the victims who had a diagnosis of a GMC

Thirty-two (46.4\%) victims were recommended as not being able to testify in court. Thirty-one (44.9\%) victims were recommended as being able to testify with the help of an intermediary and/or in camera. Only six (8.7\%) victims were recommended as being able to testify on their own in court.

A few $(n=12 ; 17.1 \%)$ victims were offered psychiatric treatment before the psychiatric recommendation to court was finalised.
Comparison of the victims based on final psychiatric recommendation to court

Two groups of victims were compared based on the psychiatrist's final recommendation to court. Of these two groups, 53.6\% of the victims were recommended as being able to testify and $46.4 \%$ of the victims were recommended as being unable to testify in court. The following variables were not statistically significantly associated with victims' ability to testify in court when comparing the two groups: gender; race; marital status; highest level of education; with whom the victim was living; place of rape incident; relation to perpetrator; number of rape incidents; and psychiatric treatment given before final evaluation.

Only two variables were statistically significantly associated with regard to the final psychiatric recommendation to court: residential category of the victim $(p=0.001)$ and mental retardation after assessment $(p=0.001)$. Victims from the rural areas $(n=11)$ (Figure 3 ) and victims with severe mental retardation were statistically significantly more often found to be unable to testify in court $(n=10)$ (Figure 4).

Figure 3: Comparison between rape victims found able to testify and those found unable to testify with respect to their residential category

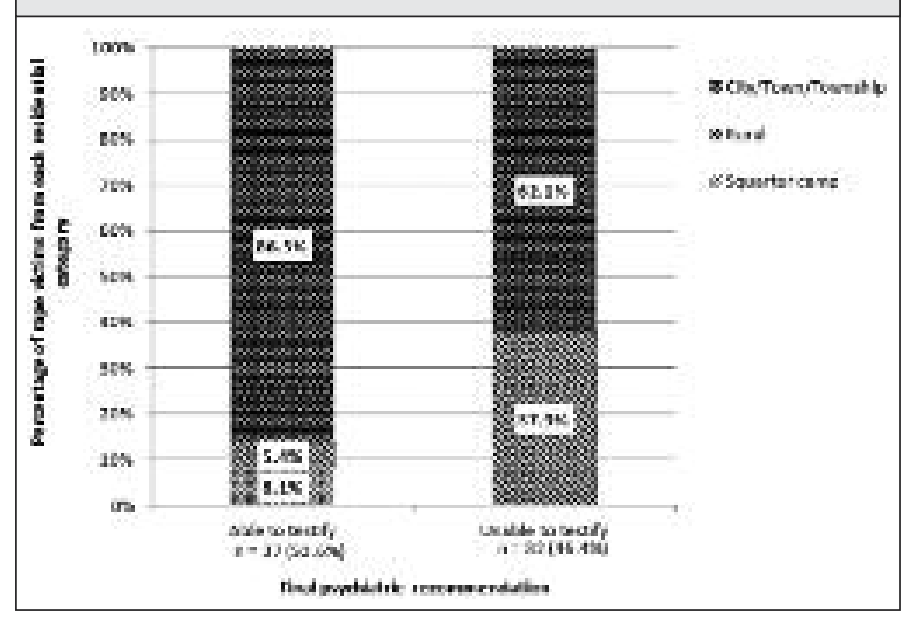

Figure 4: Comparison between rape victims found able to testify and those found unable to testify with respect to degree of mental retardation

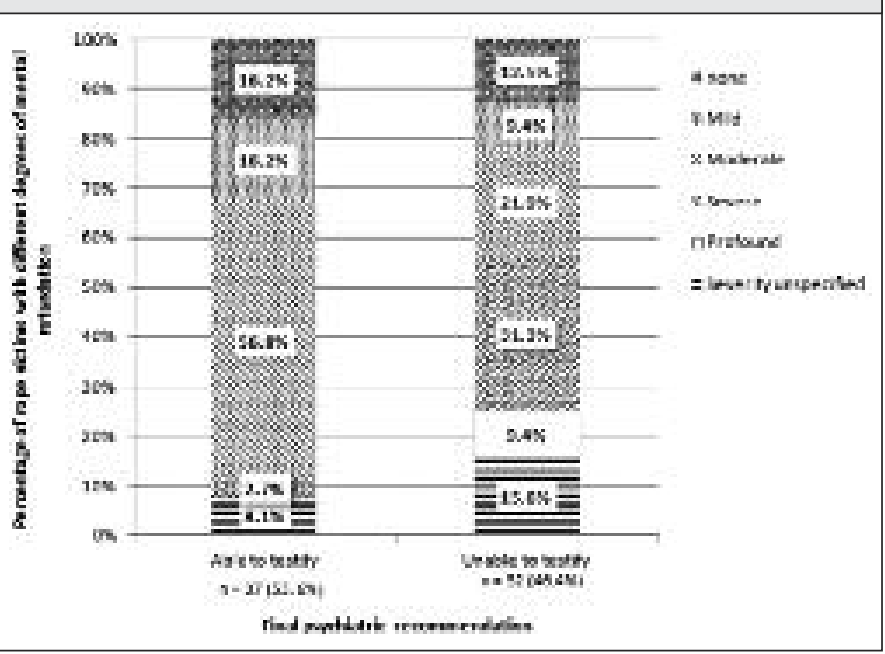




\section{Discussion}

The finding that more than half of the assessed victims were found to be able to testify, is surprising. One of the factors that might have influenced the frequency of assessments as "able to testify" might be that the Service Charter for Victims of Crime in South Africa states that every victim of a crime has the right to testify in a court of law. ${ }^{10}$ In order to gain more clarity on this finding, one might have wanted to stratify the data to investigate possible reasons for this.

In this study multiple clinical variables were assessed when comparing the two groups. However, only residential category and a diagnosis of mental retardation were statistically significantly associated with the rape victims' ability to testify in court.

Victims from rural areas were more often found to be unable to testify in court. This could have been influenced by the fact that in South Africa people from disadvantaged communities or rural areas lack special programmes that may enhance their self-esteem and communication abilities. The special programmes referred to above include special schools and sport facilities for children with developmental disabilities, occupational therapists, speech therapists and psychologists. When children are not mentally and physically stimulated, their communication abilities and self-esteem become compromised and their ability to express their emotions and opinions and to talk about a painful trauma when they have to testify in court will be severely impaired. Another contributing factor might be a lack of awareness by parents and communities concerning available services that could assist the victims with therapy, self-esteem and communication.

Rural victims' and family members' fear of retaliation by the perpetrator and of stigma in their close-knit communities might also influence the victims' ability to testify. Hence the roles of the legal services and social workers are essential in educating the communities about the assistance and protection of victims by the judicial services as stipulated in the Victims' Charter of South Africa.

Victims with severe mental retardation were more often assessed as being unable to testify in court. It would have been ideal to compare the findings of these results with previous studies; however, no studies that have assessed the rape victims' ability to testify in relation to the degrees of mental retardation were found.

The question arises whether age plays an important role in the development of psychopathology after rape. It might have been interesting to have stratified the sample according to age but the small sample size precluded such stratification. What is important is to recognise that mentally retarded individuals, no matter what their age, are at high risk both of being raped, and of developing any psychiatric disorder.

The authors had anticipated that there would be multiple clinical factors that would be statistically associated with the rape victims' ability to testify in court. However, this study demonstrated that the decision about a rape victim's ability to testify in court depends on individual clinical assessment and individual clinical factors i.e. a decision cannot be based only on the two clinical factors that were found to be statistically significant in this study. An individualised assessment remains essential so that mentally ill victims have the opportunity of testifying in court.

This study found that almost half of the victims were referred by the court to WKH within six months of being raped. This seems like a long time, considering that in some victims other biopsychosocial morbidities were detected for the first time during psycho-legal assessment. For example, a history of mood disorders before assessment was $5.4 \%$, and after assessment was found to be $40.2 \%$. And there was no history of anxiety disorders before assessment, but after assessment diagnosis of anxiety disorders was found to be $23.2 \%$. This shows that most of the rape victims with mental illness have to wait for a long time - at least six months - before being assessed properly by MHCPs. Even if the delay in the referral system was not found to affect a victim's ability to testify in court, the findings suggest that the delay in referrals will delay the detection and treatment of mental illness.

To our knowledge this is the first study of the clinical factors that are associated with rape victims' ability to testify in court and of the preliminary exploration between the judicial and the mental health services with regard to rape victims. Even if from this study a benchmark cannot be established, good and practical collaboration between the judicial and the health systems needs to be researched further. This suggested future research is vital so that the quality of care that is offered to rape victims by the judicial and the health systems in our country can be assessed and monitored.

The limitations of this study include the fact that this was a records-based study with a small sample size. Rape victims were assessed by different psychiatrists, who were not using a standardised tool for assessment. This factor had an influence on the data that was collected, as some data was missing or not recorded in the clinical file. Some variables could not be analysed due to low numbers or zeroes in many cells.

On the basis of the aforementioned discussion it is clear that a rape victim's journey through recovery and the criminal justice process requires effective collaboration between the health and judicial systems. Different roles need to be played by different professionals. The primary health care practitioners (PHCPs) - including medical officers at rape centres - need to screen, identify and diagnose mental disorders and comorbid GMCs like epilepsy in rape victims. Evidence-based screening and assessment tools need to be developed for PHCPs so that early screening and risk assessment can be made effective and early referrals to MCHPs in certain rape victims can be achieved. PHCPs need to treat and monitor conditions that are not complicated.

The current study investigated whether receiving treatment had an impact on the victim's ability to testify in court; however, the results were not statistically significant. Further studies regarding this aspect will be relevant because previous studies have shown that mental illness has an impact on the ability to testify in court. However, the influence of treatment on the victim's ability to testify remains an unanswered question. 
MHCPs need to help with training of the PHCPs. However, that initiative requires a committed involvement by the South African Department of Health. MCHPs need to do psycho-legal assessments where the courts require them to do so. However, it should not be the primary point where other comorbidities are detected and treated. Other mental illnesses and GMC should have already been assessed and treated by PHCPs.

The legal system still needs to refer the victims to MHCPs for psycho-legal assessments. However, an effective referral system needs to be developed by the health and the judicial system. PHCPs, social workers and the involved people in the judicial system can be helpful in screening the victims that need psycho-legal assessment only if effective screening methods can be validated first. This is an area that needs much improvement, attention and research.

\section{Conclusion}

The results of this study suggest that residential category and mental retardation have an impact on the rape victim's ability to testify in court. However, the decision about the victim's ability to testify in court should not be based only on these two variables, but should be individualised. Thorough psycho-legal assessment remains essential so that mentally ill victims can be offered the opportunity of testifying in court. It appears that the referral time from the courts to the MHS is lengthy, however more research is needed. Further studies are required in developing and validating screening methods as well as assessing the effective collaboration between the health and the legal system so that care of rape victims can be optimised.

\section{Acknowledgements}

The authors are grateful to Ms K Adamak (Department of Statistics, University of Pretoria) for data analysis, Ms J Jordaan (Department of Statistics, University of Pretoria) for data management, Ms B English for valuable editorial advice, and Mrs M.A. Mabena (Chief Executive Officer, Weskoppies Hospital) for enabling the research at the hospital.

\section{References}

1. South Africa. South African Police Service. [homepage on the Internet]. Crime statistics: April 2010-March 2011. Crime situations in South Africa [accessed 2011 Sep]. Available from: http://www.saps. gov.za/statistics/reports/crimestats/2011/crime_stats.htm

2. Valenti-Hein DC, Schwartz LD. Witness competency in people with mental retardation: implications for prosecution of sexual abuse. Sex Disabil 1993;11(3):287-94.

3. Campbell R. Psychological impact of rape victims. Am Psychol 2008;63(8):702-17.

4. Balogh R, Bretherton K, Whibley S, Berney T, Richold P, Worsley C, et al. Sexual abuse in children and adolescents with intellectual disability. J Intellect Disabil Res 2001;45(3):194-201

5. Faravelli C, Guigni A, Salvatori S, Ricca V. Psychopathology after rape. Am J Psychiatry 2004;161 (8):1483-5.

6. Rutter M, Bishop D, Pine D, Scott S, Stevenson J, Taylor E, et al. Eds. Rutter's child and adolescent psychiatry. 5th edition. Malden: Blackwell; 2008:440-58.

7. Calitz FJW. Psycho-legal challenges facing the mentally retarded rape victims. SAJP 2011; 17(3):66-72.

8. South Africa. Republic. Criminal law (sexual offences and related matters) amendment act no 32, 2007. Pretoria: Government Gazette; 2007 Dec 14.

9. Pillay AL. Audit of competency assessment on court referred rape survivors in South Africa. Psychol Rep 2008;103:764-70.

10. South Africa. Department of Justice and Constitutional Development. Service charter for victims of crime in South Africa. Pretoria: Department of Justice and Constitutional Development; 2007.

11. Boerzaart T. Child law in South Africa. 1st ed. Juta and Co. Ltd; 2009:563-5.

12. South Africa. Criminal Procedure Act no 51 of 1997. Pretoria: Government Gazette; 1977 Jul 22.

13. Lang AJ, Rodgers CS, Laffaye C, Satz LE, Dresselhaus TR, Stein MB. Sexual trauma, posttraumatic stress disorder, and health behavior. Behav Med 2003;28(4):150-8

14. Thomson KM, Crosby RD, Wonderlich SA, Mitchell JE, Redlin J, Demuth $G$, et al. Psychopathology and sexual trauma in childhood and adulthood. J Traum Stress 2003;16(1):35-8.

15. Sadock BJ, Sadock VA. Kaplan \& Sadock's synopsis of psychiatry: behavioral sciences / clinical psychiatry. 10th ed. Philadelphia. Lippincott Williams \& Wilkins; 2007:1 138-57.

16. Kaliski S. Psycholegal assessment in South Africa. Cape Town Oxford; 2006:287-97.

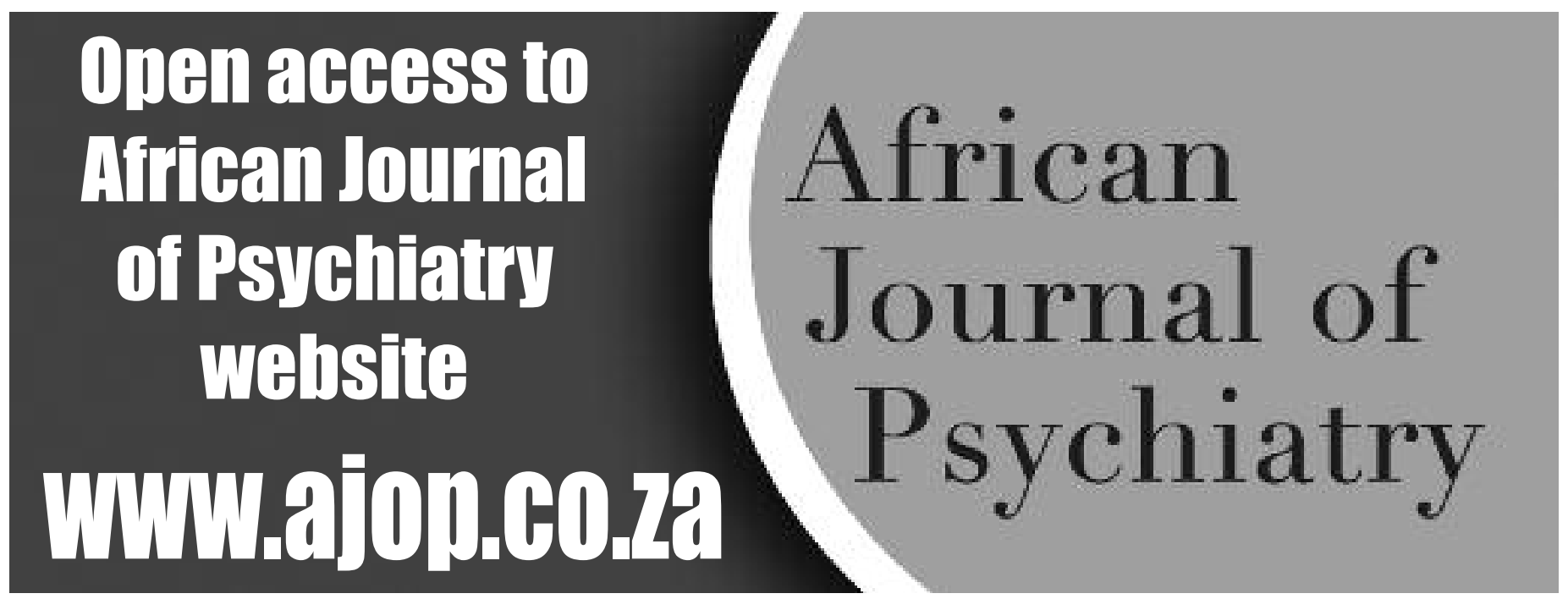

